\title{
TU YOUYOU AWARDED
NOBEL PRIZE IN MEDICINE Lucille Liu
}

I

N 2015, Tu Youyou 屠呦呦 became the first Chinese citizen to receive a Nobel Prize in medicine for her contributions to discovering the antimalarial drug artemisinin 青蒿素. She shared the prize with William C. Campbell and Satoshi Ōmura for their work in finding a novel therapy against roundworm parasites.

Tu's discovery has its roots in a secret military program. On 23 May 1967, Mao Zedong launched Project

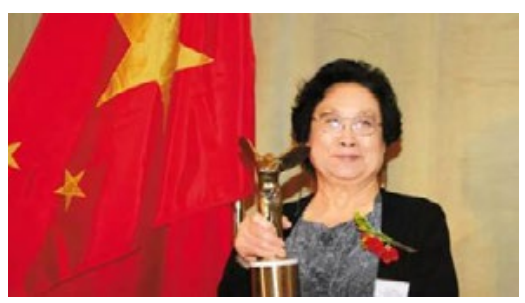

Tu Youyou

Source: img3.imgtn.bdimg.com
523 to find a cure for drug-resistant strains of malaria that were taking a huge toll on China's Viet Cong allies in the Vietnam War. In 1969, the government requested help from the China Academy of Chinese Medical Sciences (formerly China Academy of Traditional Chinese Medicine) 中国中医科学院. China was in the midst of the Cultural Revolution; many of the country's top scientists, including those that had trained overseas, had been persecuted and sent off to labour camps. Tu, who at thirty-nine held only an undergraduate degree from Beijing Medical University's School of Pharmacy and had never studied abroad, was chosen to lead the program at her institute.

Building on previous research, $\mathrm{Tu}$ and her team scoured ancient texts and interviewed traditional medicine 


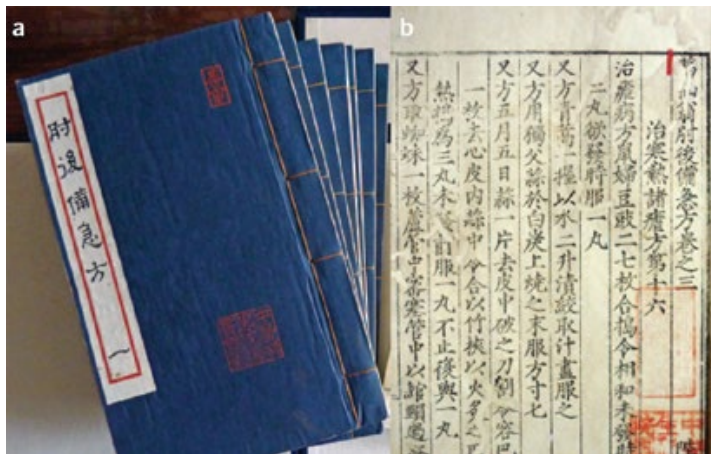

Ge Hong's Handbook of Prescriptions for Emergencies

Source: nature.com

practitioners to compile over 2,000 potential anti-malarial recipes. An extract from sweet wormwood or Artemisia annua 青蒿 produced promising, but inconsistent results when tested on malaria-infected mice.

$\mathrm{Tu}$ credits a recipe from a manual written more than two millennia ago, Ge Hong's 葛洪 Handbook of Prescriptions for Emergencies 肘后备急方 for inspiring the breakthrough that would lead to the discovery of artemisinin.

Ge's recipe called for patients to drink the juice from sweet wormwood soaked in water. Tu realised that boiling the plant might have been destroying its active ingredient and thus switched to a low temperature technique, which produced an extract that completely inhibited parasite growth in animal trials.
Premier Li Keqiang called Tu's Nobel prize 'an expression of the huge contribution that Chinese traditional medicine and pharmacy has made to the health of humankind'. The award has not been without controversy, including over whether it vindicated Chinese medicine per se or the scientific method used to identify active compounds from traditional remedies. Project 523 was also a massive government undertaking that involved over 500 scientists from sixty military and civilian institutions; $\mathrm{Tu}$ was one of many working on the project. Tu herself has told The New York Times that she considered the honour of the Nobel to belong collectively to herself, her team, and the nation. 
This text is taken from China Story Yearbook 2015: Pollution, edited by Gloria Davies, Jeremy Goldkorn and Luigi Tomba, published 2016 by ANU Press, The Australian National University, Canberra, Australia. 